Etnográfica

Revista do Centro em Rede de Investigação em

Antropologia

vol. 21 (3) | 2017

Vol. 21 (3)

\title{
Notas etnográficas sobre o empreendedorismo em favelas cariocas
}

Ethnographic notes about entrepreneurship in favelas in Rio de Janeiro

\section{Marcella Carvalho de Araujo Silva}

\section{(2) OpenEdition}

Journals

\section{Edição electrónica}

URL: https://journals.openedition.org/etnografica/5056

DOI: 10.4000/etnografica.5056

ISSN: 2182-2891

\section{Editora}

Centro em Rede de Investigação em Antropologia

\section{Edição impressa}

Data de publição: 1 outubro 2017

Paginação: 585-598

ISSN: 0873-6561

\section{Refêrencia eletrónica}

Marcella Carvalho de Araujo Silva «Notas etnográficas sobre o empreendedorismo em favelas

cariocas », Etnográfica [Online], vol. 21 (3) | 2017, posto online no dia 24 março 2018, consultado o 11 fevereiro 2022. URL: http://journals.openedition.org/etnografica/5056 ; DOI: https://doi.org/10.4000/ etnografica. 5056

Etnográfica is licensed under a Creative Commons Attribution-NonCommercial 4.0 International License. 


\section{Notas etnográficas \\ sobre o empreendedorismo em favelas cariocas}

\section{Marcella Carvalho de Araujo Silva}

Estas notas etnográficas procuram fazer uma descrição preliminar do processo de construção social do empreendedorismo em favelas do Rio de Janeiro e dos ajustamentos a essa nova ideologia econômica, por parte de grupos de moradores. Em primeiro lugar, exploro os trabalhos de mediação de técnicos de programas de inclusão produtiva. Em segundo lugar, volto-me ao exercício de imaginação de lideranças comunitárias, que viram o empreendedorismo se abrir como possibilidade de financiamento público-privado às suas atividades associativas. Faço uma descrição etnográfica desses dois momentos como trabalhos de tradução - o primeiro preocupado com a produção de relatórios de formalização; o segundo interessado em capitalizar novos recursos ao financiamento do associativismo local. O objetivo do artigo é explicitar os mecanismos sociais de produção do "sucesso" de programas de desenvolvimento local.

PALAVRAS-CHAVE: empreendedorismo, inclusão produtiva, geração de trabalho e renda, favelas, informalidade, mediação política.

Ethnographic notes about entrepreneurship in favelas in Rio de Janeiro - This paper gives an ethnographic account of the social construction of entrepreneurship in Rio de Janeiro's favelas and the related adjustments of grassroots groups to this economic ideology. The paper has two goals. First, it analyzes the work of mediation done by project managers with beneficiaries of productive inclusion programs. Secondly, it explores the exercise of imagination carried out by community leaders, for whom entrepreneurship programs have opened avenue for public-private financing. The paper argues that both activities should be rendered as "works of translation" - the former concerning filing formalization reports of small businesses, the latter striving to strengthen grassroots association. Such ethnographic account aims to unveil the social mechanisms manufacturing the "successfulness" of local development programs.

KEYWORDS: entrepreneurship, productive inclusion, work and income, favelas, informality, political mediation.

SILVA, Marcella Carvalho de Araujo (marcella.caarsi@gmail.com) - Departamento de Sociologia, Universidade Federal do Rio de Janeiro, Brasil. 


\section{INTRODUÇÃO}

"A gente vai virar ONG ou empresa?", perguntou uma das integrantes de um coletivo de economia solidária a uma colega, no primeiro semestre de $2013 .{ }^{1}$ Regina estava preocupada com as questões institucionais envolvidas na formalização do grupo, de modo a ter acesso a financiamento público-privado. Àquele momento, as cinco mulheres haviam sido convidadas a participar de um grupo de trabalho sobre desenvolvimento social e econômico em favelas, no âmbito do Fórum Nacional, associação dos autointitulados "principais economistas, sociólogos e cientistas políticos brasileiros, iniciada em 1988 com a finalidade de oferecer propostas concretas para a modernização da sociedade brasileira". ${ }^{2}$

Desde 2010, o empreendedorismo se colocava no horizonte de favelas com Unidades de Polícia Pacificadora (UPP), na cidade do Rio de Janeiro. ${ }^{3}$ Após ocupações militares dos territórios de mais de 30 complexos de favelas da cidade, inúmeros programas sociais foram direcionados a elas. O governo do estado apostava que o controle da circulação de armas permitiria a "abertura de mercado" e a "chegada do Estado" aos territórios de favelas. Entre gestores de programas de inclusão produtiva da prefeitura, havia uma percepção compartilhada de que a "chegada das UPP" finalmente permitiria a desarticulação do tráfico de drogas e o desenvolvimento econômico desses territórios.

Neste trabalho, reconstruo brevemente minha participação como assistente de pesquisa de um consultor do Banco Mundial, responsável por uma avaliação dos programas de inclusão produtiva no Rio de Janeiro. Por meio de contatos em comum, ele chegou até a professora Mariana Cavalcanti, com que eu trabalho há muitos anos, e ela me indicou como assistente de pesquisa, dada minha experiência com trabalho de campo em favelas. O consultor, que prefiro não nomear aqui, precisava de alguém que pudesse mediar seu acesso às favelas e com quem ele pudesse dividir tarefas. Eu não apenas o acompanhei nas entrevistas preliminares com coordenadores de programas de inclusão produtiva, como agendei entrevistas com técnicos em campo, realizei pequenas incursões de acompanhamento do dia a dia dos programas nos territórios e entrevistei beneficiários.

l Este artigo é fruto de algumas experiências de campo do início do meu doutorado. Mercados de trabalho e empresariamento de trabalhadores por conta própria são dois dos temas que investiguei em minha tese sobre a provisão de habitação social, intitulada Obras, Casas e Contas: Uma Etnografia de Problemas Domésticos de Trabalhadores Urbanos, no Rio de Janeiro e defendida em setembro de 2017 (M.A.C. Silva 2017).

2 Ver < http://www.inae.org.br/sobre/ > (última consulta em outubro de 2017).

3 As Unidades de Polícia Pacificadora são um programa de segurança pública, criado em 2008, em que contingentes policiais ocupam os territórios de complexos de favelas, com o objetivo de diminuir a circulação de armas. Sobre os rituais de pacificação, cf. M.C.A. Silva (2012). Vale destacar que, desde o término dos Jogos Olímpicos 2016, em meio à crise econômica por que passa o país e o estado do Rio de Janeiro em particular, as UPP estão em processo de desmantelamento. 
Inicialmente, o objetivo da pesquisa era analisar a relação entre a inclusão produtiva, a urbanização (realizada pelas obras do PAC - Programa de Aceleração do Crescimento) e a "pacificação de favelas" (realizada pelas UPP), tomando alguns casos como controle. Contudo, após uma primeira rodada de entrevistas com os gestores responsáveis pelos programas de inclusão produtiva na cidade do Rio de Janeiro, percebemos um viés nesse recorte, pois os programas de empreendedorismo eram implantados apenas em favelas com Unidades de Polícia Pacificadora. Sem levar isso em consideração, acabaríamos por atribuir peso indevido à pacificação no que diz respeito à "abertura de mercado". Infelizmente não havia tempo nem equipe suficiente para criar grupos de controle e analisar as relações específicas entre urbanização e inclusão produtiva, por um lado, e pacificação e inclusão produtiva, por outro. O objetivo da pesquisa foi então reformulado e fizemos uma comparação dos efeitos de programas de inclusão produtiva sobre o mercado de trabalho em duas regiões da cidade, uma na Zona Sul e outra na Zona Norte. Optámos então por direcionar os esforços de campo a dois conjuntos de favelas: o Complexo do Alemão ${ }^{4}$ e o Pavão-Pavãozinho e Cantagalo. ${ }^{5}$

Essa experiência de pesquisa me causou algumas inquietações, desde logo pela distância de vocabulários e expectativas entre o consultor e os gestores, de um lado, e os beneficiários, de outro. Em algumas entrevistas, tive que reformular as perguntas que o consultor fazia, ininteligíveis àqueles moradores de favelas, que, pelos mais variados motivos, se tornavam "empreendedores". Além disso, havia uma enorme dissonância entre os dados dos gestores e as narrativas dos beneficiários sobre o "processo de formalização".

Em paralelo a essa pesquisa, eu seguia acompanhando um coletivo composto por diversos grupos de uma favela na Zona Norte, tanto em suas reuniões internas regulares, como no diálogo com o Fórum Nacional, acima mencionado. Os programas de inclusão produtiva da prefeitura também funcionavam nessa favela, que havia passado pela ocupação militar em 2010 e cujas dinâmicas políticas eu acompanhava desde 2009. Com o convite do coletivo a integrar as discussões sobre desenvolvimento econômico de favelas organizadas pelo Fórum Nacional, além da possibilidade de formalização de pequenos negócios, o empreendedorismo se colocava no horizonte político como fonte de financiamento ao associativismo local.

4 O Complexo do Alemão fica na região do antigo subúrbio industrial da Leopoldina, na Zona Norte da cidade, e é composto por 15 favelas. Ele foi escolhido em virtude da desindustrialização recente por que passou, cujos desdobramentos nas oportunidades de trabalho gostaríamos de compreender. Há mais de 18 mil domicílios e 60 mil moradores, segundo os dados do Censo 2010.

5 Pavão, Pavãozinho e Cantagalo são três favelas localizadas entre os bairros de Copacabana e Ipanema, na Zona Sul da cidade do Rio. Elas foram escolhidas por historicamente constituírem um mercado de serviços às classes mais altas da região. Há ali cerca de 3000 domicílios e mais de 10.000 moradores. 
Este artigo é então o fruto da reflexão sobre essas duas experiências. Como assistente de pesquisa de um consultor do Banco Mundial, pude analisar como o "empreendedorismo" estava sendo construído como uma lente para enxergar, compreender e propor soluções ao "problema da geração de trabalho e renda". Essa experiência, mesmo que curta, foi bastante profícua em elucidar os meandros da produção dos dados sobre empreendedorismo. Por outro lado, minha longa experiência de campo em uma favela com extenso histórico associativo me permitiu acompanhar o esforço de imaginação coletiva que lideranças empreendiam, de modo a costurar aquilo que elas já vinham realizando ao horizonte de possibilidade aberto pelos programas de empreendedorismo. Nesse sentido, as notas etnográficas procuram descrever, ainda que parcialmente, o processo de construção social do empreendedorismo em favelas do Rio de Janeiro e os ajustamentos operados por grupos de moradores a essa nova ideologia.

Faço uma descrição etnográfica do trabalho de mediação dos técnicos e do exercício de imaginação das lideranças como "trabalhos de tradução" - o primeiro preocupado com a produção de relatórios de formalização; o segundo interessado em capitalizar novos recursos para o financiamento do associativismo local. Meu objetivo é explicitar as operações invisíveis de ajustamento que, tanto quanto os processos de produção de dados de "sucesso" pelos técnicos, são fundamentais para que o empreendedorismo se efetive. Segundo Benjamin (2008 [1923]), a tarefa de tradução implica fidelidade ao sentido dos originais e não literalidade. Aproprio-me dessa perspectiva para analisar o duplo "esforço de identificação interessada" da linguagem do empreendedorismo. De um lado, os técnicos traduzem como empreendedorismo as mais variadas atividades de trabalho realizadas por moradores de favelas, preocupados em cumprir as metas dos programas de inclusão produtiva e produzir relatórios e números. Por outro, as lideranças comunitárias estão comprometidas em dizer nas palavras dos financiadores aquilo que já vêm fazendo.

\section{"FORMALIZANDO OS INFORMAIS", CRIANDO EMPREENDEDORES}

A instabilidade econômica e a reestruturação produtiva dos anos 1980 e 1990 mobilizaram a atenção de muitos cientistas sociais no Brasil. O fim do horizonte de assalariamento e seus efeitos em termos de inserção urbana e formas de associativismo (Rizek 2012) colocaram questões acerca dos "sentidos e lugares do trabalho na tessitura do mundo social" (Telles 2006: 173). Em meio a essas transformações, houve, por um lado, uma "autonomização" do problema da pobreza em relação ao mundo do trabalho (Rizek 2006) e, por outro, uma ampla reflexão sobre os desafios da empregabilidade dos amplos contingentes de desempregados e subempregados (Cardoso, Caruso e Castro 1997; L.A. M. Silva e Chinelli 1997; L.A. M. Silva 2002). 
A década de 2000, por sua vez, testemunhou a retomada do crescimento econômico acompanhado da geração de empregos formais e da distribuição de renda, via valorização do salário mínimo e políticas de transferência de renda. $\mathrm{Na}$ virada da década, nos anos 2010, gestores públicos ligados à Secretaria de Assuntos Estratégicos da Presidência da República não se furtaram a afirmar que as melhorias nas condições de vida da população brasileira haveriam promovido uma transformação na estrutura de classes sociais (Neri 2010). A sociologia do mercado de trabalho, por seu lado, vem procurando criticar essa perspectiva oficial, por meio de estudos das novas configurações do trabalho formal (Guimarães 201 l), da estrutura ocupacional brasileira (Cardoso 2016a) e do papel de políticas públicas de combate à informalidade (Cardoso 2016b). Este artigo pretende somar a essa reflexão, problematizando a produção de dados de sucesso sobre a formalização do trabalho e o empreendedorismo.

Em 2013, à época do estudo do Banco Mundial de que participei, o objetivo principal era avaliar o papel das políticas públicas no combate à informalidade. No mapeamento dos programas que comporiam o estudo de caso, identificamos uma miríade de atividades voltadas à "inclusão produtiva": assessoria a empreendedores, mediação com bancos, capacitação para o turismo, formação de agentes comunitários, organização do comércio local em circuitos gastronômicos e turísticos, oferta de balcão de empregos, qualificação profissional, etc. ${ }^{6}$ Estava no horizonte do consultor o universo espetaculoso do empreendedorismo amplamente noticiado, como na reportagem "Turbinando o DNA empreendedor" (O Globo, 1 1/02/2012), ${ }^{7}$ que apontava "Il mil microempreendedores" apenas nas favelas da Rocinha e do Complexo do Alemão. A pesquisa do Banco Mundial pretendia então avaliar o desempenho dos programas em garantir o sucesso econômico desses atores.

Após o mapeamento dos programas, começamos as entrevistas pelos gestores. O objetivo dos programas de inclusão produtiva seria duplo: por um lado, prover qualificação para o mercado de trabalho, para que os beneficiários encontrassem empregos como assalariados; por outro, formalizar os prestadores de serviços, garantindo-lhes acesso a crédito e inserindo-os em redes comerciais de maior escopo. Essas duas estratégias tinham como propósito "tirar as pessoas da informalidade" e "inseri-las no mercado de trabalho". Tanto para o coordenador da pesquisa de que eu participava, como para os gestores dos programas de inclusão produtiva, se bem-sucedidos, os beneficiários deveriam

6 Foram entrevistados coordenadores dos programas Empresa Bacana (do Instituto Pereira Passos, da prefeitura do Rio), PAC Social (da Empresa de Obras Públicas, do governo do estado), Sesi Cidadania (da Federação de Indústrias do Rio de Janeiro), Empregabilidade (da ONG Afroreggae), Programa Renda Melhor (da Secretaria Estadual de Assistência Social e Direitos Humanos), e Sebrae Desenvolvimento de Comunidades Pacificadas (do Serviço Brasileiro de Apoio a Micro e Pequenas Empresas). 7 Disponível em <http://oglobo.globo.com/economia/turbinando-dna-empreendedor-3949790> (última consulta em outubro de 2017). 
concluir os cursos e o processo de formalização com uma única atividade de trabalho formal - assalariado ou autônomo - e aumento da renda. Esses eram os dois critérios indicativos de "sucesso".

Contudo, na prática, havia muita dificuldade em cumpri-los e os relatórios de monitoramento indicavam sistemático fracasso. Para os gestores, cujo próprio desempenho profissional era avaliado pelos resultados obtidos, os critérios de sucesso deveriam ser alterados. A gestora do programa Sesi Cidadania, ${ }^{8}$ composto por educação básica e profissional, oficinas culturais e inclusão digital, estava, naquele momento, sugerindo à direção do programa que a própria favela fosse considerada um mercado de trabalho, em demonstração de profundo desconhecimento das dinâmicas econômicas de décadas nas favelas cariocas. Essas dificuldades encontradas pelos gestores fazem ecoar os dois grandes desafios atuais do mercado de trabalho, destacados por Cardoso (2016a): o crescimento insuficiente do mercado formal, por um lado, e a não empregabilidade de parcela significativa dos $40 \%$ da população informalmente empregada, por outro.

As possibilidades efetivas de geração de trabalho e renda e as experiências dos beneficiários entrevistados em 2013 indicavam que os trabalhos formal e informal constituíam um continuиm em suas vidas e nas de suas famílias, em uma composição de atividades e rendimentos que Machado da Silva (1971) e Machado da Silva e L. Lopes (1979) já haviam estudado nos anos 1970. Esses eram os casos do pintor Luiz, demitido de uma empreiteira, que estava procurando dispor de "nota fiscal carioca" " para poder prestar seu serviço para arquitetos e contratantes individuais, e da ex-empregada doméstica com carteira assinada, Bia, que sempre complementou seu salário mínimo com a prestação de serviços como cabeleireira, que então ela pretendia transformar de "bico" em negócio.

A perspectiva de fracasso assombrava e desanimava muito o consultor do Banco Mundial. Ele insistiu, algumas vezes, que as nossas idas a campo em horário comercial estavam enviesando as informações obtidas, pois aquelas pessoas que se teriam qualificado profissionalmente "não estariam nas favelas, mas trabalhando". Ele achava muito significativo que alguns cursos de capacitação profissional fossem oferecidos de madrugada, entre meia-noite e $4 \mathrm{~h}$ da manhã ou entre $4 \mathrm{~h}$ e $7 \mathrm{~h}$, sinal, segundo ele, de demanda por horários que não conflitassem com as jornadas de trabalho. Contudo, não conseguimos localizar nenhum beneficiário desses cursos. E ele relutava em aceitar que as dezenas

8 Conjunto de iniciativas do Serviço Social da Indústria, direcionado a complexos de favelas com UPP (ver < http://www.firjan.com.br/sesi/qualidade-de-vida/sesi-cidadania/default.htm >, última consulta em outubro de 2017).

9 Segundo o site da prefeitura do Rio: "A Nota Fiscal de Serviços Eletrônica (NFS-e) é um documento que substitui as tradicionais notas fiscais impressas. A NFS-e implantada pela Secretaria Municipal de Fazenda simplifica a vida dos prestadores de serviços, dos cidadãos e das empresas da cidade" (<https://notacarioca.rio.gov.br/>, última consulta em outubro de 2017). 
de cursos oferecidos pelos programas servissem apenas para "fazer currículo" e "fazer contatos", como nos diziam os entrevistados.

Das 32 entrevistas com beneficiários que fizemos, apenas dois entrevistados mencionaram ter "entrado para o mercado de trabalho", nesses termos. Contudo, um caso era de um jovem que cursava a universidade, não sendo possível afirmar se o emprego assalariado estava diretamente relacionado ao programa de inclusão produtiva ou à sua educação superior. O outro caso dizia respeito a um soldador que estava no seu oitavo curso de capacitação profissional no Sistema S. ${ }^{10}$ Para Carlos, os cursos serviam "para fazer currículo": os professores indicavam os melhores alunos a empregos e os próprios alunos criavam redes de contato para divulgação de vagas e oportunidades de trabalho. Se os cursos e os programas sociais garantiam uma porta de acesso a trabalhos por produção, como autônomo, Carlos, no entanto, não deixava de conciliá-los com "bicos" como pedreiro e com o seu negócio de transporte escolar. Seu caso, nos critérios dos gestores, continuava a ser indicador de fracasso.

No dia a dia dos atendimentos, cabia aos técnicos dos programas efetuar a formalização e acompanhar os desafios dos novos empreendedores. No Complexo do Alemão, o Sebrae funcionava na favela da Nova Brasília e os atendimentos aconteciam na recepção da Praça do Conhecimento, um espaço de biblioteca, informática e entretenimento, um dos muitos equipamentos coletivos construídos pelas obras de urbanização do Programa de Aceleração do Crescimento. Ana, a técnica do Sebrae, permanecia sentada em uma mesa de plástico, em um canto da entrada do equipamento, aguardando os moradores "buscarem o programa”, divulgado por panfletos em alguns eventos comunitários.

Segundo essa técnica, cujo trabalho acompanhei por um dia, o processo de formalização era interessante por dar acesso a microcrédito, facilitar a compra de produtos e, nos casos de prestadores de serviços, permitir a emissão de "nota fiscal carioca". A formalização era feita em duas etapas. Primeiro, no caso daqueles que tinham negócios, os beneficiários levavam as fichas de cadastramento do Sebrae até a inspetoria responsável pela área e davam entrada ao processo de "busca prévia de local", para que o alvará do estabelecimento fosse concedido. Em seguida, eles retornavam ao plantão do Sebrae e finalizavam o cadastro no Portal do Empreendedor. ${ }^{11}$ Para aqueles beneficiários que ofereciam serviços, como pintura, carpintaria, marcenaria, construção, etc., bastava realizar o cadastro no site. Nenhum dos beneficiários atendidos no dia em que

10 O Sistema S é composto por: Serviço Nacional de Aprendizagem Industrial (Senai), Serviço Social do Comércio (Sesc), Serviço Social da Indústria (Sesi) e Serviço Nacional de Aprendizagem do Comércio (Senac). Existem ainda os seguintes: Serviço Nacional de Aprendizagem Rural (Senar), Serviço Nacional de Aprendizagem do Cooperativismo (Sescoop) e Serviço Social de Transporte (Sest) (ver $<$ http://wwwl2.senado.leg.br/noticias/glossario-legislativo/sistema-s $>$, última consulta em outubro de 2017).

11 Ver < http://www.portaldoempreendedor.gov.br/ > (última consulta em outubro de 2017). 
a acompanhei em campo já havia obtido o alvará. Segundo a técnica, a burocracia era o principal problema enfrentado no processo de formalização. As inspetorias não reconheciam alguns endereços e/ou não sabiam qual delas era responsável por determinadas "áreas de comunidade".

Como tive que realizar as entrevistas com beneficiários na própria mesa que a técnica usava - ela me convidou a sentar ao seu lado e solicitava a algumas pessoas que me dessem entrevistas -, o tempo que eu tive para conversar com eles se resumiu ao tempo que ali gastavam. Para os "empreendedores natos", como $O$ Globo se refere a esses atores, "tempo é dinheiro". Algumas das pessoas que passaram pelo plantão não foram entrevistadas e outras me deram entrevistas muito precárias e, em alguns casos, enviesadas, pela interferência de Ana nas respostas. Ao ouvir dos empreendedores que sua principal motivação para a formalização dizia respeito à contribuição previdenciária, ${ }^{12}$ ela intercedia e perguntava: "E o que mais?" Eles completavam então, vagamente, que "também queriam organizar tudo". Ana também intervinha no vocabulário empregado por eles e o adaptava, dizia que eles eram "empresários" e que "empresário não tem lojinha [em tom pejorativo]; tem loja".

A busca por beneficiários do programa Empresa Bacana, ${ }^{13}$ do Instituto Pereira Passos (IPP), da prefeitura do Rio, elucidou ainda mais as dissonâncias entre técnicos e beneficiários. Segundo dados do programa, no Complexo do Alemão, haveria mais de 130 empreendedores atendidos pelo "mutirão de formalização", realizado em parceria entre o IPP e o Sebrae, no dia da "Ação Global". E no Pavão-Pavãozinho e Cantagalo haveria cerca de 70 beneficiários. Minha primeira tentativa de contato, via telefone, com os empreendedores das extensas listas fornecidas pela gestora do programa foi completamente infrutífera. Telefonei a pelo menos dez beneficiários do Complexo do Alemão, mas ou os números estavam incorretos, ou pertenciam a outra pessoa, ou, no caso do único beneficiário a me atender, minha ligação causava desconfiança - ele suspeitou, como outros, que eu fosse da fiscalização ou quisesse "fazer cobrança".

Em campo no Pavãozinho, pedi a ajuda da agente Sesi Cidadania na localização dos beneficiários. ${ }^{14}$ Renata ficou muito intrigada ao ver o nome de seu

12 A motivação dos 15 empreendedores que conheci no plantão do Sebrae era começar a pagar o Imposto Nacional de Seguridade Social - mais conhecido por sua sigla INSS.

13 O programa Empresa Bacana foi encerrado nos últimos anos. Seus objetivos eram regularizar negócios em áreas pacificadas da cidade, em ação coordenada entre o Sebrae, a Secretaria de Ordem Pública e o Sindicato de Empresas e Serviços Contábeis. Completando um ano de existência, em 2011 , o programa afirmava ter formalizado mais de 1330 empreendedores em áreas com UPP. Mais informações em < http://www.rio.ri.gov.br/web/ipp/exibeconteudo?article-id=2151118> (última consulta em outubro de 2017).

14 Os programas sociais no Brasil contratam moradores de favelas e periferias como "agentes comunitários”, como são chamados no Rio, para a implementação de suas ações. Investiguei o surgimento dessa figura e os desdobramentos políticos de sua atuação em minha dissertação de mestrado (M.C.A. Silva 2013). 
pai na planilha que eu carregava. Em primeiro lugar, porque ela não sabia que ele havia participado do "mutirão de formalização", cujo acontecimento ela mesma desconhecia. Mas principalmente porque parecia estranho a ela que a "vendinha" do seu pai, em vias de ser fechada, constasse naquela "planilha de empreendedores". Guiada por Renata, percorri diversas ruas do Pavãozinho em busca dos nomes listados, mas encontramos muitos estabelecimentos comerciais fechados. Conseguimos, de todo modo, contatar alguns deles, cujos relatos negativos seguem abaixo.

Paulo conversou comigo muito desconfiado. Ele me disse que a formalização só servira pelo CNPJ (Cadastro Nacional de Pessoas Jurídicas), que facilitava a compra de material de construção que ele vende. Fora isso, a formalização o onerou, pois, além do imposto simples, específico a microempreendedores individuais, ${ }^{15}$ ele tinha que pagar mensalmente à Cielo, empresa brasileira adquirente multibandeira, pelo uso de máquina de cartão de débito e crédito. Ele havia tentado pegar empréstimo em três bancos, mas não obtivera êxito e achava que isso se devia à "desconfiança" dos bancos em relação a estabelecimentos localizados em favelas. Muito sisudo, Paulo disse que pretendia fechar aquela que é a sua última loja remanescente - já havia fechado a primeira e estava desistindo de abrir uma terceira - e voltar a trabalhar como bombeiro hidráulico, sua profissão.

Com a ajuda e a companhia de Renata, encontrei uma segunda "empreendedora". Inicialmente, a mulher estava desconfiada, achando que se tratava de "cobrança". Lucia começou a fazer artesanato (como ela mesma se referiu à sua atividade), anos atrás, com o dinheiro que recebia pela internação de dois de seus seis filhos em um reformatório. Passou anos vendendo as bijuterias que fazia e revendendo roupas em uma "barraquinha" na Rua Saint Romain, que dá acesso à favela do Pavãozinho. Com o "choque de ordem", operação da Secretaria de Ordem Pública que impede a atuação de ambulantes em determinados pontos da cidade, Lucia havia perdido seu ponto de venda. Em seguida, tentou montar barracas na Ladeira dos Tabajaras, mas a perda de material para o "rapa", como são popularmente chamadas as apreensões de produtos de ambulantes e camelôs pela polícia ou guarda municipal, fez com que ela desistisse do seu negócio. Lucia restringiu então suas vendas a clientes que já conheciam o seu trabalho e a procuravam em sua casa, no Casarão, espécie de cortiço com quase 30 cômodos, demolido pelas obras do PAC e substituído por um conjunto habitacional no mesmo local. Quando do "mutirão de formali-

15 O microempreendedor individual é uma figura jurídica brasileira, criada em 2008, pela Lei Complementar 128/2008, que modificou a Lei Geral da Micro e Pequena Empresa. Desde o ano de sua criação até 2017, os microempreendedores individuais poderiam ter faturamentos de até 60000 reais anuais. A partir de 2018, o valor foi elevado para 81000 reais. Eles podem contar com apenas um funcionário com carteira assinada. Mais informação em < http://www.portaldoempreendedor.gov.br > (última consulta em outubro de 2017). 
zação", ela viu uma oportunidade de recuperar o fôlego de suas vendas. Mas, sem estabelecimento comercial próprio, a formalização significava apenas o pagamento de um boleto mensal e Lucia desistiu de ser "microempreendedora individual".

Lucia nos levou até uma terceira "empreendedora" da lista de contatos. O caso de Jaqueline elucidou ainda mais problemas acerca da produção daquela lista de 74 "empreendedores". Jaqueline era dona de casa e não conseguia entender como se tornou "microempreendedora individual". Ela havia ido ao "mutirão" solicitar esclarecimentos sobre como pagar o INSS. E lá a pessoa que preenchia as fichas buscou formas de traduzir a sua vida de dona de casa naquelas categorias do "empreendedorismo". Tinha crianças em casa, além do filho? Não. Não poderia ser considerada babá. Fazia comida? Sim, para a família. E assim, nas fichas, Jaqueline passou a ser "fornecedora de alimentos preparados preponderantemente para consumo domiciliar". Mensalmente, recebia os boletos para pagar e não entendia o porquê, se não tem um "negócio". Após alguns meses de idas e vindas à Rua da Ajuda, no Centro, conseguiu deixar de ser "microempreendedora individual".

\section{"A FAVELA COMO OPORTUNIDADE"}

No dia 16 de maio de 2013, foi realizada, na sede do BNDES (Banco Nacional de Desenvolvimento Econômico e Social), no centro do Rio, a mesa "Plano de Inclusão Econômica e Social de Favelas", como parte do XXV Fórum Nacional. ${ }^{16}$ Fala central e com grande destaque foi a de Marília Pastuk, socióloga mentora da ideia "favela como oportunidade" de mercado, cuja história remontava ao "Plano de Inclusão Econômica e Social", pensado a partir do "Projeto de Integração Social de Comunidades". Em 2010, "considerando o lado preventivo da segurança", "problema que evolui pari passu com o desenvolvimento do narcotráfico e com a favelização da cidade", o Fórum Nacional havia incorporado projetos de "integração social" às suas propostas de desenvolvimento. Esse projeto teria lançado a base para as "demandas" das favelas listadas em publicações posteriores. No ano seguinte, 2011 , foram desenvolvidas as "Bases Preliminares para um Plano de Integração" e, em 2012, nasceu o projeto "Favela como Oportunidade", compilando as demandas de lideranças comunitárias, com o objetivo de "desenvolvimento territorial".

16 Compunham a mesa: o ex-ministro de planejamento Reis Velloso, o arcebispo do Rio de Janeiro, Marília Pastuk, da Ação Comunitária do Brasil, a diretora do IPP e da UPP Social, o secretário de Assistência Social e Direitos Humanos, o representante do prefeito, o representante do vice-governador, o presidente do Conselho de Responsabilidade Social da Firjan, o diretor das áreas de infraestrutura social, meio ambiente e agropecuária, e inclusão social do BNDES, a representante do PAC Social, a Fundação Oswaldo Cruz, a Federação de Favelas do Rio de Janeiro, e as lideranças comunitárias do Borel, Rocinha, Cantagalo, Pavão e Pavãozinho, Manguinhos, Jacarezinho e Alemão. 
Integrante do colegiado do Fórum Nacional desde 2010, o coletivo de ONGs da favela que eu vinha acompanhando, naquele março de 2013, se viu diante da oportunidade de financiamento do BNDES. A proposta apresentada era criar e desenvolver um projeto de geração de emprego e renda para a favela. Desde então, reuniões e mais reuniões vinham se desenrolando, com o intuito de escrever um "projeto guarda-chuva", que congregasse todos os projetos que já eram desenvolvidos por entidades locais e também os "empreendedores" em iniciativas que levassem ao "desenvolvimento sustentável”. A dúvida entre "virar" ONG ou empresa, com que abri este artigo, nasceu daí. Com todas as facilidades de realização de um cadastro como "microempreendedores individuais", oferecidas pelo Sebrae a "comunidades pacificadas", o formato associativo havia se tornado uma questão premente entre coletivos organizados em favelas que compunham o colegiado do Fórum.

A ideia de um "projeto guarda-chuva" pretendia que todas as iniciativas já realizadas pelo coletivo fossem agrupadas em um único "circuito turístico", enquadramento adotado por todas as comunidades do colegiado. As lideranças comunitárias tinham então a expectativa de formação de um mercado turístico naquele ano que antecedia a Copa 2014 e as Olimpíadas 2016. ${ }^{17}$ Esse circuito turístico permitiria, na visão das lideranças locais, que a concepção de "geração de emprego e renda" do BNDES abarcasse tudo aquilo que o coletivo já fazia. Em inúmeras reuniões comunitárias, o mote foi exatamente traduzir a rede local em um circuito turístico, a ser coordenado por uma "agência de desenvolvimento local". Meu trabalho junto às lideranças foi de mapeamento dos grupos, listagem de suas atividades, construção de objetivos - todos eles de "geração de trabalho e renda" -, reflexão sobre estratégias de marketing e propaganda, e formulação de uma tabela de demandas de estruturação.

O formato "agência", que supõe "troca de serviços", como salientou a liderança Marta, tinha o objetivo de construir uma "cadeia produtiva" entre os participantes, agrupados em quatro eixos de atuação que "abarcariam toda a economia local": polo gastronômico, polo cultural, polo ambiental e comunicação. A expectativa era que os grupos e "empreendedores" locais se associassem à agência, de modo a ter acesso aos cursos de capacitação profissional e aos "selos de qualidade" que a agência pretendia oferecer, em parceria com programas governamentais e/ou outras instituições - aquelas mesmas que mapeei na consultoria do Banco Mundial. As taxas pagas pelos associados, por sua vez, seriam empregadas no pagamento de um corpo administrativo e em custeio de pessoal, que não eram atividades financiadas pelo BNDES.

Nesse esforço imaginativo, o trabalho de tradução das lideranças era duplo. Por um lado, havia um esforço de traduzir um circuito político em circuito

17 Sobre o turismo em favelas pacificadas no Rio de Janeiro, conferir Freire-Medeiros, Vilarouca e Menezes (2016). 
econômico, o que teve efeitos perversos de desarticulação e concorrência entre lideranças, cada uma avaliando as possibilidades de seus grupos auferirem maiores financiamentos individualmente ou como parte da "Agência". Por outro, na produção das planilhas de mapeamento, as lideranças traduziam um conjunto de iniciativas de "inclusão social" que desenvolviam na nova linguagem da "inclusão produtiva".

Esse exercício de imaginação e tradução criou um dilema moral. A "hipocrisia" ${ }^{18}$ se tornou uma preocupação constante, tanto no que dizia respeito à quebra da horizontalidade do coletivo de ONGs, com a sobreposição de uma "Agência" e possivelmente de uma liderança às demais, como à negociação com um agente do mercado para a obtenção de recursos para "fazer política". O conflito entre o projeto do Fórum Nacional, "que tem cara de social, mas é como se fosse empresa", e a percepção de que o coletivo de ONGs "não deveria perder essa oportunidade de financiamento às suas ações" resume bem os paradoxos que o empreendedorismo como horizonte político criou.

\section{POR UMA ETNOGRAFIA DAS MEDIAÇÕES}

Ao longo dos anos que se seguiram, as iniciativas do Fórum Nacional perderam fôlego. O projeto guarda-chuva do coletivo de ONGs não foi adiante. O próprio coletivo foi esmorecendo, cada liderança se voltando para suas atividades específicas. Desde 2015, com o acirramento da crise econômica brasileira, particularmente aguda no estado do Rio, as fontes de investimento secaram.

Estas notas etnográficas, em alguma medida, se tornaram notas históricas, de uma cidade que se acenava virtualmente, mas que não chegou a se concretizar de todo. De qualquer modo, elas continuam tendo relevância metodológica. Por um lado, seguindo o trabalho de David Mosse (2005), é particularmente importante estudar o processo de produção social do sucesso de políticas de desenvolvimento. Em um contexto de financiamento internacional, com modelização e replicação de boas práticas, compreender como são produzidos papéis, documentos e números oficiais permite elucidar práticas e assinaturas estatais contemporâneas (Das e Poole 2004).

Por outro lado, a etnografia das mediações permite compreender quais são as justificações dadas por empreendedores morais (Becker 2009 [1963]) e os ajustamentos feitos por aqueles que devem ser convencidos. Vista de fora, a relação entre o Fórum Nacional e as lideranças comunitárias, nesses dois papéis, respectivamente, poderia ser entendida como cooptação. A meu ver,

18 Weber (2004 [1904]) fala da "hipocrisia das virtudes", acerca do manual de Benjamin Franklin, como capacidade produtiva das aparências. Boltanski (2013) retoma essa noção em sua formulação sobre a absorção da crítica por modos de dominação, destacando o caráter hipócrita da ação dos dominantes. 
porém, devemos analisar os ajustamentos como potencialmente criativos, em que atores competentes, como as lideranças de favelas, analisam e captam a lógica de ideologias que se lhes impõem e procuram brechas que permitam subversões por dentro. É verdade que essas apropriações e ressignificações acabam por reforçar dados oficiais e estatísticas, que leituras mais apressadas e superficiais podem entender como sinais de sucesso de tais ideologias. No entanto, são também elas que criam espaços para a reinvenção de práticas e lógicas, para a mudança, apesar da continuidade.

\section{BIBLIOGRAFIA}

BECKER, Howard S., 2009 [1963], "Empreendedores morais", em Howard S. Becker, Outsiders: Estudos de Sociologia do Desvio. Rio de Janeiro, Jorge Zahar Editor, 153-168.

BENJAMIN, Walter, 2008 [1923], A Tarefa do Tradutor, de Walter Benjamin: Quatro Traduções para o Português. Belo Horizonte, Fale/UFMG, org. Lucia Castello Branco.

BOLTANSKI, Luc, 2013, "Sociologia da crítica, instituições e o novo modo de dominação gestionária”, Sociologia \& Antropologia, 3 (6): 441-463.

CARDOSO, Adalberto, 2016a, "Brazilian labour market: limits and opportunities for emancipation”, em A. Cardoso, Work in Brazil: Essays in Historical and Economic Sociology. Rio de Janeiro, EdUERJ, 173-214.

CARDOSO, Adalberto, 2016b, "Informality and public policies to overcome it: the case of Brasil”, Sociologia \& Antropologia, 3 (2): 321-349.

CARDOSO, Adalberto, Luis Antônio CARUSO, e Nadya CASTRO, 1997, “Trajetórias ocupacionais, desemprego e empregabilidade: há algo de novo na agenda dos estudos sociais do trabalho no Brasil?", Contemporaneidade e Educação, 2 (1): 7-23.

DAS, Veena, e Deborah POOLE (orgs.), 2004, Anthropology in the Margins of the State. Santa Fe, SAR Press.

FreIRE-MEDEIROS, Bianca, Márcio Grijó VILAROUCA, e Palloma MENEZES, 2016, "A pobreza turística no mercado de pacificação: reflexões a partir da experiência da Favela Santa Marta", Caderno CRH, 29 (78): 1-16.

GUIMARÃES, Nadya Araujo, 2011, "As novas configurações do trabalho formal: algumas reflexões à luz do caso de São Paulo", Anais do 35. "Encontro Anual da ANPOCS. Caxambu, ANPOCS, disponível em < https://anpocs.com/index.php/encontros/papers/ 35-encontro-anual-da-anpocs/gt-29/gt36-5/1249-as-novas-configuracoes-do-trabalhoformal-algumas-reflexoes-a-luz-do-caso-de-sao-paulo/file > (última consulta em outubro de 2017).

MOSSE, David, 2005, Cultivating Development: An Ethnography of Aid Policy and Practice. Londres, Pluto Press.

NERI, Marcelo Cortes (org.), 2010, A Nova Classe Média: O Lado Brilhante dos Pobres. Rio de Janeiro, FGV/CPS. 
RIZEK, Cibele Saliba, 2006, "Viração e trabalho", Estudos de Sociologia, 11 (21): 49-58.

RIZEK, Cibele Saliba, 2012, “Trabalho, moradia e cidade: zonas de indiferenciação?”, Revista Brasileira de Ciências Sociais, 27 (78): 41-49.

SILVA, Luiz Antonio Machado da, 1971, Mercados Metropolitanos de Trabalho Manual e Marginalidade. Rio de Janeiro, programa de pós-graduação em Antropologia Social, Universidade Federal do Rio de Janeiro, dissertação de mestrado em Antropologia.

SILVA, Luiz Antonio Machado da, 2002, "Da informalidade à empregabilidade: reorganizando a dominação no mundo do trabalho”. Caderno CRH, Salvador, 37: 81-109.

SILVA, Luiz Antonio Machado da, e Filippina CHINELLI, 1997, "Velhas e novas questões sobre a informalização do trabalho no Brasil atual”, Contemporaneidade e Educação, 2 (1): 24-45.

SILVA, Luiz Antonio Machado da, e José Sérgio de Leite LOPES, 1979, "Introdução: estratégias de trabalho, formas de dominação na produção e subordinação doméstica de trabalhadores urbanos", em J.S. L. Lopes et al. (orgs.), Mudança Social no Nordeste: A Reprodução da Subordinação. Rio de Janeiro, Paz e Terra, 9-40.

SILVA, Marcella Carvalho de Araujo, 2012, "Rio em forma olímpica: a construção social da pacificação na cidade do Rio de Janeiro”, em Michel Misse e Alexandre Werneck (orgs.), Conflitos de (Grande) Interesse: Estudos sobre Crimes, Violências e Outras Disputas Conflituosas. Rio de Janeiro, Garamond, 115-128.

SILVA, Marcella Carvalho de Araujo, 2013, A Transformação da Política na Favela: Um Estudo de Caso sobre os Agentes Comunitários. Rio de Janeiro, programa de pós-graduação em Sociologia e Antropologia, UFRJ, dissertação de mestrado em Sociologia.

SILVA, Marcella Carvalho de Araujo, 2017, Obras, Casas e Contas: Uma Etnografia de Problemas Domésticos de Trabalhadores Urbanos, no Rio de Janeiro. Rio de Janeiro, Universidade do Estado do Rio de Janeiro, tese de doutorado em Sociologia.

TELLES, Vera da Silva, 2006, "Mutações no trabalho e experiência urbana", Tempo Social, 18 (1): 173-195.

Weber, Max, 2004 [1904], A Ética Protestante e o Espírito do Capitalismo. Rio de Janeiro, Companhia das Letras. 